\title{
The Transmedia News Coverage of the 2016 Rio Olympics*
}

Renira Rampaz:o Gambarato

DOI: https://doi.org/10.17230/9789587206289ch4

Geane Carvalho Al:amorai

Lorena Peret Teixeira Tárciaii

\section{Introduction}

This paper wishes to examine how transmedia features were structured and implemented by the official Brazilian broadcaster Globo Network (Rede Globo, in Portuguese), in the news coverage of the 2016 Rio Summer Olympics. Globo Network, the largest in Brazil, had the non-exclusive right to transmit the Games on television and the exclusive rights for cable television, Internet, and mobile phone broadcast (UOL, 2015). During the Games, Globo Network (in partnership with the Japanese broadcasting organization NHK) aired the live Opening and Closing ceremonies in ultra-high-definition $8 \mathrm{~K}$ format (Lobo, 2016). Other innovations included sports commentators' use of augmented reality, and high-definition images on the network's Internet streaming service, Globo Play, as part of a strategic move to gain market share and boost Globo Network businesses domestically and internationally.

- This work was originally published in the book Exploring Transmedia Journalism in the Digital Age (Chapter 8, pp. 126-146), edited by Renira Rampazzo Gambarato and Geane Alzamora (2018). That version has been revised and edited for the current publication.

i Bachelor of Industrial Design at São Paulo State University, Master's Degree and Ph.D. in Communication and Semiotics at Pontifical Catholic University of São Paulo, Brazil; Postdoctorate in Film Studies and Semiotics at Concordia University, Canada. Associate Professor in Media and Communication Studies at Jönköping University School of Education and Communication, Sweden. Email: renira.gambarato@ju.se

ii Bachelor of Social Communication-Journalism at Pontifical Catholic University of Minas Gerais, Brazil; Master's Degree and Ph.D. in Communication and Semiotics at Pontifical Catholic University of São Paulo. Associate Professor of the Department of Social Communication and the Postgraduate Program at the Federal University of Minas Gerais, Brazil. Email: geanealzamora@gmail.com

iii Bachelor of Social Communication-Journalism and Master's Degree in Education at Pontifical Catholic University of Minas Gerais; Ph.D. in Social Communication at the Federal University of Minas Gerais. Associate Professor in the Department of Social Communication at the University Center of Belo Horizonte, Brazil. Email: lorenatarcia2@gmail.com 
The theoretical framework focuses on transmedia journalism (Gambarato \& Alzamora, 2018; Moloney, 2011; Renó, 2014) of planned events (Dayan \& Katz, 1992; Gambarato, Alzamora, \& Tárcia, 2016; Gambarato \& Tárcia, 2017; Getz, 2012; Hepp \& Couldry, 2010). The methodology is based on the analytical and operational model for transmedia news coverage of planned events developed by Gambarato and Tárcia (2017). The research findings indicate that the content was expanded throughout various media platforms, but involved limited audience engagement mechanisms.

\section{Transmedia journalism of planned events}

Henry Jenkins' (2006) conceptualization of transmedia storytelling refers to robust franchises distributed across multiple media platforms, where this type of storytelling unfolds story-worlds throughout diverse media outlets and embraces audience engagement as a core element of transmedia experiences. On the other hand, transmedia journalism presents dynamics similar to those of transmedia storytelling but applied to entertainment, magnifying news narratives through diverse platforms that involve citizen participation. Audiences can participate by adding, editing, and sharing news via digital media. Gambarato and Tárcia (2017) argue:

In sum, we consider that transmedia journalism, as well as other applications of TS [transmedia storytelling] in fictional and nonfictional realms, is characterized by the involvement of (1) multiple media platforms, (2) content expansion, and (3) audience engagement. Transmedia journalism can take advantage of different media platforms such as television, radio, print media, and, above all, the internet and mobile media to tell deeper stories. Content expansion, as opposed to the repetition of the same message across multiple platforms, is the essence of TS [transmedia storytelling] and, therefore, should be the focal point of transmedia journalism as well. The enrichment of the narrative is facilitated by the extended content. Audience engagement involves mechanisms of interactivity, such as the selection of the elements to be explored, the option to read a text, watch a video, enlarge photographs, access maps, click on hyperlinks, and share information through social networks. Audience engagement deals with participation via, for instance, remixing content and creating original user-generated content (p. 1387). 
Characteristic of transmedia storytelling is the direct inclusion of the ad hoc/contingent and the planned/strategic creations aspects related to transmedia journalism. To start with, Fast and Örnebring (2015) discuss the ad hoc/emergent nature of transmedia storytelling by highlighting the fact that transmedia worlds can evolve over time and can be co-created both by professionals and amateurs, while the planned/strategic essence of transmedia productions considers the companies' careful structuring and narrative portioning across multiple media platforms. Among these features, transmedia journalism combines the "carefully orchestrated company strategies" (Fast \& Örnebring, 2015, p. 2) and the commodification of media texts (Bolin, 2007; Freeman, 2016b) with the ad hoc nature of audience engagement within transmedia experiences. Gambarato and Tárcia (2017) emphasize on the planned aspect of transmedia journalism optimization, because it becomes a proactive process that is carried out by the journalists who assume the responsibility to design a storyworld in which the audience can be engaged. Although transmedia-breaking news journalism is possible, Moloney (2011) argues that "daily journalism, with its time-constrained brevity, is not a viable option. Transmedia must be designed carefully and developed with a lengthy lead time to be effective" (p. 12). In addition, Renó (2014) reinforces the need to design and plan not only the content to be produced but also the way in which the audience will experience it.

Planned events are well schematized temporal occurrences, publicized in advance. They are noteworthy occurrences within a special set of circumstances at a given place and time, with a detailed program and schedule known in advance (Getz, 2012). Getz proposes an experiential planned event typology that embraces mega-events, media events, participant events, and so forth, which are organized consistently with their functions and meanings: (1) cultural celebrations (festivals, carnivals, heritage commemorations, religious rites, etc.), (2) business and trade (meetings, conventions, fairs, exhibitions, etc.), (3) arts and entertainment (concerts, shows, installations, award ceremonies), (4) political and state (summits, political congresses, military events, etc.), (5) private functions (rites of passage, weddings, funerals, etc.), and (6) sport and recreation (championships, tours, fun events, etc.).

The term media event was introduced and gained visibility after Dayan and Katz's (1992) mass communication studies focused on live, 
real-time broadcasting of extraordinary, pre-planned public events. Hepp and Couldry (2010) extended the conceptualization of media events, discussing the globalized and multifaceted power structure of communication processes reinforced by the role of the Internet and multiplatform production in media cultures from the Digital Age. Likewise, recent publications about media events (Fox, 2016; Mitu \& Poulakidakos, 2016) draw on Dayan and Katz's (1992) concepts and challenge the live broadcasting and printed media assumptions, typical of mass communication, by incorporating the social media reality into the debate. Thus, planned events transmedia news coverage is comprehensive and encompasses much more than the sports sphere. The relevance of planned events transmedia journalism relies on the fact that these usually entail (1) ad hoc/emergent aspects, attracting large domestic and international audiences, potentially engaging and integrating them in the news-making process, and (2) planned/strategic aspects, involving a significant amount of human, technical, and financial resources, and providing numerous protagonists, primary and parallel stories (Gambarato \& Tárcia, 2017).

As discussed by Gambarato, Alzamora and Tárcia (2016), the multiplatform global news coverage of planned events where citizens also produce and distribute content is a practice that gained traction, especially during the 2012 London Summer Olympics. Due to the British Broadcasting Corporation (BBC) coverage of the 2012 Games, London Olympics are considered the "first truly digital Olympics" (O'Riordan, 2012, § 3). The Olympics in London (with multiscreen production) and Sochi in 2014 (with the addition of discreet hints of transmedia features in the coverage) confirmed the emergence of a distinct scenario in journalism: a hybrid of the mass media transmission logic and the social media sharing logic, which blurs off the distinctions between professionals and amateurs, producers and users. This blend of information/content production and consumption, or produsage (Bruns, 2008), and its subsequent engagement of audiences, by creating communities around the storyworlds and usergenerated content (UGC), is a core principle of transmedia experiences (Jenkins, 2006), in the fiction and nonfiction realms. UGC concerns media content freely created, circulated, and consumed by the public, including, for instance, "blogs, wikis, discussion forums, posts, chats, tweets, podcasts, and pins, delivered in text, image, video, or audio modes" (Smith, Stavros, \& Westberg, 2017, p. 59). 
Lewis (2012) suggests that "the struggle between the professional logic of control, embedded in journalism's ideology, and the participatory logic of free engagement, embedded in the substance and culture of digital media" (2012, p. 850) is paving the way for the emergence of "a hybrid logic of adaptability and openness: a willingness to see audiences on a more peer level, to appreciate their contributions, and to find normative purpose in transparency and participation, $\grave{a}$ la open-source technology culture" (p. 851).

\section{Methodology of analysis}

The analysis of transmedia strategies for planned events news coverage aims at a clearer understanding of transmedia news production and to boost and improve transmedia journalistic practices. The method chosen for the transmedia analysis of Globo Network news coverage during the 2016 Summer Olympics is the analytical and operational model for planned events, proposed by Gambarato and Tárcia (2017). This model addresses the specificities of such multiplatform news productions by clarifying how transmedia features are structured and implemented. Identifying transmedia strategies of journalistic coverage backs the analytical and operational purposes of both scholars and journalists interested in the contemporary news media industry. As proposed by Freeman (2016a), "our role as media industry studies scholars is perhaps to be brainstormers and analysts to help theoretically advance cutting-edge media industry workings" (p. 205). The method draws the analytical model developed by Gambarato (2013) on transmedia project design and establishes 10 main topics and subsequent practicable questions, regarding, for instance, news storytelling, media platforms, and audience engagement. A schematic representation of the model is provided in Figure 1. Similarly, this model has been applied to analyze the transmedia dynamics during the 2014 Sochi Winter Olympic Games regarding the Russian news coverage (see Gambarato, Alzamora, \& Tárcia, 2016) and the Brazilian news coverage of the 2014 FIFA World Cup (see Gambarato, Alzamora, Tárcia, \& Jurno, 2017). 
Figure 1. Schematic representation of the transmedia analytical model for the news coverage of planned events by Gambarato \& Tárcia (2017)

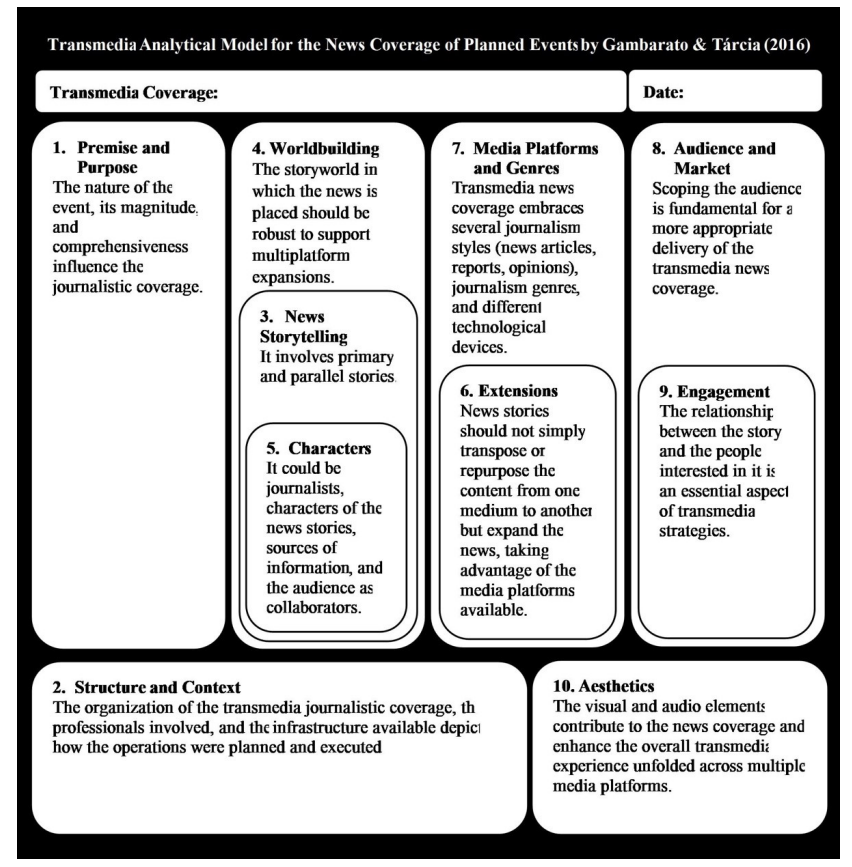

Source: Authors.

\section{The Transmedia News Coverage of the 2016 Rio Olympics}

\section{Premise and Purpose}

The 2016 Summer Olympics took place in Brazil on August 2016. More than 11,000 athletes represented 205 National Olympic Committees, including first-time entrants Kosovo, South Sudan, and the Refugee Olympic Team. Three hundred six events, spanning 42 sports disciplines, occurred across 32 competition venues over 16 days (Long, 2016).

Although the fundamental objects of the coverage were the competitions, the athletes, and their performances, the media also had to be aware of issues connected to the coverage. This scenario included the coverage of (1) social and political demonstrations and controversies, (2) 
an ongoing outbreak of the mosquito-borne Zika virus in Brazil, (3) the pollution of Guanabara Bay, whose waters were used for sailing and windsurfing competitions, (4) political instability and economic crises, and (5) the Russian doping scandal and participation restrictions, for instance.

\section{Structure and Context}

For the 2016 Summer Olympics in Rio, Brazilian television channels Globo Network, Record Network, and Bandeirantes Network were responsible for generating the international radio and TV signals. More than 7.000 hours of video and audio coverage were produced and distributed to an audience of six billion people over 220 countries (Long, 2016). Globo Network planned a multiplatform coverage of the Games which included online streaming, social media networks, mobile applications, and websites. The websites still remain live and updated.

The broadcaster's public-facing operations took place inside the network's Olympic Studio facility, located in the heart of the Olympic Park. Globo Network allegedly invested around US\$250 million in this coverage (Feltrin, 2016). This structure and the large investment contributed to effectively execute the planned transmedia strategies for the news coverage.

\section{News Storytelling}

The news coverage of the 2016 Rio Games involved different kinds of stories. In general, the primary stories broadcasted, especially on television, were directly related to the sports events, such as the Olympic competitions, games' results, and stories about the athletes being portrayed as heroes. However, parallel stories, especially when shared via social media in conjunction with mass media, were also diffused widely. Some of the highlighted parallel stories included (1) American Olympic swimmer Ryan Lochte fabricating a story about being robbed at gunpoint during the Games, (2) two boxers arrested and accused of trying to rape housekeepers, (3) Patrick Hickey, a top Olympic official, arrested after illegally selling tickets to the Games, and (4) an Olympic media bus attacked on a highway. The secondary stories, in conjunction with the primary ones, enriched the coverage and functioned as crucial elements to expand the content during the transmedia coverage. 


\section{World-Building}

The event was set throughout Rio de Janeiro, which provided an opportunity to construct worlds under different aspects. The broadcaster built the concept "we are all Olympians", upon which the network based its actions to involve and engage the audience. The warm-up for the Games started in March 2016, and around 2.500 related news pieces were aired before the Opening Ceremony.

The Olympics were big enough to support expansions throughout multiplatform coverage. Globo Group, comprising Globo Network (television), Globosat (cable television), Infoglobo (printed media), and Globo Radio System (radio), involved several of the group's content platforms in this coverage, although the same had not occurred over the 2014 FIFA World Cup (Gambarato et al., 2017). On this occasion, Globo Group created different concepts for each media platform, a core characteristic of transmedia storytelling and consequently, of transmedia journalism. On one hand, cable television, with over a 1,000 professionals involved, provided a broad experience of the Games. On the other hand, printed media, under the premise of "digital first", delivered material to websites, mobile applications, and e-books, in addition to special magazines. Furthermore, a free printed tabloid paper was distributed, as well as a guide to the Olympics.

A special digital environment followed the competitions in real time and focused on interactivity with users; infographics, photo galleries, videos, quizzes, mini-documentaries, etc. were also available. While some specific actions encouraged users' involvement through posts and comments on social networks, the coverage also offered a competitionbased game, divided into stages, in which the player scored points by answering Games related questions. Moreover, a mobile application was developed to provide updated information and news about competitions, as well as itineraries for the event's day-to-day schedule. For example, the application even mentioned which bars would transmit the competitions, venues where fans from a certain country were getting together, as well as other services. The newspapers focused on stories about citizenship, optimism, overcoming difficulties, inclusion, and other Olympic values. By offering material and services to make the most while at the city, Infoglobo served as an alternative for brands wanting to play host 
to tourists and communicate directly with them. The radio operations concentrated on information, thrills, and humor throughout bulletins and programs, always striving to present Olympic sports in an easier and practical manner to the audience.

\section{Characters}

In mega-events such as the Olympics, a complex storyworld with multiple highlighted characters as part of the coverage are proposed by both the journalists and/or by the event organizers. Several people, in addition to the array of international athletes, were the focus of the news coverage in 2016. Although the regulations imposed by the International Olympic Committee (IOC) are considered strict, especially regarding social media, the visibility of the Globo Network studio in the Olympic Park created a different phenomenon in these Olympics. During the main televised broadcasts, many people congested the front of the building and ended up being incorporated into the show. Even with this initiative, the excessive control, regulations, and economic interests restricted the audience's overall capability to actively participate in the news coverage. Therefore, the audience cannot be considered a leading character in the media coverage of this event.

Daily data collected during the Olympics remarked numerous prominent athletes and non-athlete characters. For instance, despite Olympic officials' efforts to avoid an uncomfortable scenario, Brazilian residents loudly booed interim President Michel Temer as he opened the Games. He did not receive an introduction to the crowd, which is a standard for the leaders of the host countries; the event was one of the first official gatherings that Michel Temer had attended since becoming the country's president on August 31, 2016, after President Dilma Rousseff was impeached and removed from office. Olympics fans, in general, and social media users, in particular, were neither necessarily aware of nor worried about the IOC restrictions: during the Games, spectators were expelled from Olympic venues for wearing T-shirts criticizing Michel Temer. In addition, while spectators were ordered by members of the security forces to put away signs with political messages, a Brazilian federal judge ruled in favor of allowing peaceful political protests at the Olympic Games in Rio. Not surprisingly, it was the Globo Group who covered this controversy on all platforms. Gisele Bundchen, the world's highest-paid supermodel, also 
featured the 2016 Olympics Opening Ceremony, when she walked the length of the Maracanã Stadium to the sound of "Girl from Ipanema". As a result, Spotify reported that the song was streamed over 40,000 times the day after her appearance, representing an increase of $1.200 \%$ over usual streaming ratings (Bromwich, 2016).

\section{Extensions}

Despite the restrictions imposed by the IOC, Globo Network planned the "biggest coverage in the broadcaster's history after the inauguration of its Olympic Studio" (Rede Globo, 2016c, § 1). Primarily, the extended coverage involved all the Globo Group media platforms: television, printed media, Internet, and radio. For instance, Globo Group's cable sports channel SportTV directly broadcasted $100 \%$ of the competitions, using 56 signals across television and the Internet. Subscribers could choose among 56 broadcasting options available in computers, tablets, and smartphones applications. The video-on-demand Sport TV Play platform offered special programs and an interactive video player that displayed pause and rewind options, allowing users to choose events according to the date and sport (Rede Globo, 2016a). Likewise, the SportTV Rio 2016 mobile application granted users exclusive access to the channel's schedule and medals table. In this application, which operated with augmented reality technology, the user could activate alerts to receive notifications about the events schedule and information about their favorite athletes, as well as access to a services guide to Rio de Janeiro that showed tourist attractions, means of transportation, bike rentals, police stations, hospitals, and health centers in three languages: Portuguese, Spanish, and English (Rede Globo, 2016b).

Although it still prioritized a mass media logic of transmission, this distinctive coverage included several multiplatform extensions based on the Olympic Studio. The content aired on this multiscreen environment enabled various possibilities for exploring journalistic content and interaction via social media, mediated by the hashtag \#SomosTodosOlímpicos [\#WeAreAllOlympians], with posts exhibited live on a large screen at the Olympic Studio. The aim was to update the content on the different media platforms during the news coverage, while promoting audience engagement via social media interactions. In an unprecedented partnership (Rede Globo, 2016a), the profile "Snapredeglobo" offered specific 
content for the feature "Live Stories" on Snapchat, including behind the scenes photos and videos recorded by journalists, commentators, and fans. Thus, a news coverage strategy was established based on multiplatform broadcasting, where specific content was allotted to foster engagement under certain extensions.

\section{Media Platforms and Genres}

The multiplatform perspective that outlined the Olympic Games news coverage produced by Globo Network involved numerous journalistic styles, such as news stories, articles, interviews, and opinion pieces. Television broadcasts prevailed among the journalistic strategy, particularly in relation to national news and sports programs on its public access channel, such as Globo Esporte. On one side, public access broadcasts favored the most popular sports in the country, such as football, volleyball, and gymnastics, as well as competitions in which Brazilian athletes participated. On the other, broadcasts on cable channels favored specific sports. In both cases, there was a strong correlation with the Internet via websites, applications, and profiles on online social media networks.

For instance, the website globoesporte.com broadcasted $100 \%$ of the Olympic Games events on two live streaming channels, with scores on the website's homepage being updated in real time. Also, the videoon-demand platform Globo Play offered free content that completed the public access channel on a 24-hour basis. Additionally, users could also access competitions that had already happened from an on-demand catalogue that listed athletes, sports, and participating nations. Although the multiplatform coverage of the event focused mainly on television and the Internet, radio and printed media were also included.

In sum, the content produced by Globo Network, in the scope of the broadcaster's multiplatform coverage of the Olympic Games, was complementary and eventually redundant, favoring users' choices depending on their mediatic consumption habits. In this sense, it was possible to identify the valorization of second screen applications and geolocation, as well as the interaction on online social media networks, stemming from journalistic content offered by the broadcaster. 


\section{Audience and Market}

The multiplatform audience of Globo Network registered an unparalleled growth rate during the Games. The cable channel Sport TV, Globo's main channel for this event, reached 38 million people during the 2,400 hours of broadcasting in 17 days. This number is $27 \%$ bigger than the three direct competitors (ESPN, Fox, and BandSports) sum of spectators and 29\% bigger than the total number of spectators reached by SportTV during the 2012 London Olympics coverage. During the Rio Olympics, SportTV and Sport TV2 took the lead in prime-time cable television (Stycer, 2016).

Regarding the impact of the event on the different media platforms used, televised broadcasting registered a $40 \%$ increase, in comparison to the 2012 London Olympics. Between August 3 and August 21, 2016, the free-to-air Globo Network channel reached 177 million people, which represents 53.5 million people more than during the 2012 London Games, corresponding to a $43 \%$ increase. The group's digital platforms recorded 6.5 million users in the audience peaks during the Opening and Closing Ceremonies transmissions. The broadcast of the Closing Ceremony drew a 27 audience rating, the highest since the 1996 Atlanta Olympics. Furthermore, globoesporte.com reached a daily average of 15 million accesses during the Games, and a historical record was set during the women's football semi-final between Brazil and Sweden: 20.1 million views (Mermelstein, 2016). These numbers show that the multiplatform coverage strategy was successful: Globo Network beat audience records and became the leader of that segment, reaching a varied public with a robust and diversified editorial project. However, this does not mean that citizen participation widely permeated the editorial planning, even if participation was discernible in specific contexts, notably on the online social media networks.

\section{Engagement}

Globo Network attained the most engagement, in comparison to any brand, on online social media during the 2016 Rio Olympic Games (Soutelo, 2016). Throughout the Games, Globo Network's profile on Twitter posted 1,800 tweets, generating around 180,000 shares. The hashtag \#SomosTodosOlímpicos, created by the broadcaster, was mentioned 234,000 times on Twitter between August 3 and August 21, 2016. This 
was 10 times more than what was measured for the hashtag \#NBCOlympics posted by the American television network NBC, which registered 22.000 mentions on Twitter during the same period. Globo Network's coverage became a trending topic on Brazilian Twitter 509 times and on the global Trending Topics list 165 times. Facebook registered around 830 posts with the hashtag \#SomosTodosOlímpicos, which generated around 6 million accesses. On Instagram, this hashtag was deployed for around 630 posts, with nearly 5.8 million likes. On Snapchat, the broadcaster's profile registered about 730.000 daily visits (Soutelo, 2016).

The engagement generated on online social media networks, especially when mediated by the hashtag put forward by Globo Network, indicates that the hashtag acted as a symbolic articulation of the broadcaster's posts on social media. This mechanism of interaction stimulates social involvement in news dissemination, based on contemporary habits of information consumption, and this hashtag boosted Globo Network's presence on online social media connections. This element is extremely important for the editorial strategy adopted in its multiplatforms, because it emphasizes the relevance of online social media networks in the diffusion of journalistic content.

In this sense, the Olympic Games became the most talked-about event ever on Instagram, with 916 million interactions between 131 million Instagram users $(G 1,2016)$. Overall, the broadcaster's audience engagement strategy privileged interaction in detriment of participation. Interaction presupposes that the audience can "act/react/interact but cannot interfere with the narrative" in the sense that the "audience can decide the path to experiencing it, can click here or there, can react to social media entries, but it is not able to collaborate and co-create" (Gambarato, 2012, p. 76). Participation implies co-creation to engage the audience "in a way that expresses their creativity in a unique, and surprising manner, allowing them to influence the final result" (Gambarato, 2012, p. 74). In this scenario, the IOC rules and regulations played a major role, decreasing the opportunities to foster participation during the Games.

\section{Aesthetics}

The aesthetic perspective of the Globo Network coverage of the Olympic Games excelled in journalistic accuracy, combined with technological 
innovation. On one hand, for instance, no language innovations achieved an incorporation of virtual reality narratives or newsgames in content expansion. On the other, editorial planning produced sophisticated strategies of broadcasting and information access, made available by the broadcaster throughout multiple media platforms. As an example, the use of augmented reality in mobile applications, such as Globo Rio 2016, allowed the audience to point their smartphones at a competition venue and receive real time information about what was happening at that specific location. Globolinha, the coverage's mascot, could be visualized by users when accessing data about ongoing matches based on geolocation, in a similar aesthetics as Pokémon Go. Thus, augmented reality was added to the Games transmissions in real time and enriched the audience experience.

Technological advances such as the holographic projections resulted from the partnership between Globo Network and the Japanese broadcasting organization NHK for live transmissions in the ultra-high-definition (UHD) $8 \mathrm{~K}$ format to cover the Opening and Closing Ceremonies. The $8 \mathrm{~K}$ technology defines a cutting-edge standard in image quality, offering a resolution 16 times better than the current high-definition (HD) used in digital television (Lobo, 2016). This noteworthy broadcasting, however, did not bring a direct transmedia expansion in the journalistic narrative.

\section{Research findings and final remarks}

Transmedia journalism essentially implies (1) multiple media platforms, (2) content expansion, and (3) audience engagement. The Globo Network news coverage embraced, to a certain extent, all three core dimensions of transmedia phenomena. In relation to diversified media platforms, Globo Network took advantage of the consortium of subsidiary media outlets within the Globo Group, incorporating television, Internet, printed media, social media, and radio. The mothership of the coverage was television and the second-screen experience offered to the audience. Notwithstanding, social media networks, such as Instagram and Snapchat, played a major role in the expansion of content and audience engagement. The 2016 Summer Olympics, also called the Games of Snapchat stories and filters (Barkho, 2016) became the most "instagramed" event in history 
(G1, 2016). Globo Network stablished an unprecedented partnership with Snapchat to offer live, behind-the-scenes, broadcasts from various perspectives. Social media, as a source of news, is a global trend that has been studied by multiple renowned institutions (see Gottfried \& Shearer, 2016; Newman, Fletcher, Levy, \& Nielsen, 2016), and the Olympics followed this trend. Although the Snapchat platform was not originally designed to be a news source, this is currently so prevalent that the firm adjusted its services to insert transmedia journalism. A highlight of the Globo Network Games coverage was the carefully orchestrated strategy and the proactive planned process carried out by the journalists, who structured an up-front transmedia approach.

Globo Network focused on interactivity with users to the detriment of effective citizen participation, where the opportunities for the public to interact involved infographics, quizzes, polls, posts, comments, and sharing. The mobile applications developed by Globo Network for the event contributed to audience interaction, for example, via the augmented reality tools and the geolocation systems incorporated into the applications. Few hints of participation were present in specific situations, especially connected to the direct broadcasts from the Olympic Studio in the middle of the Olympic Park, where people gathered in front of the studio and were incorporated into the transmission. Nonetheless, the strict set of regulations foisted by the IOC on the public and media organizations allegedly interfered with the hybrid logic of adaptability and openness (Lewis, 2012), inherent to audience participation in journalism.

In a nutshell, even though the Globo Network coverage was aligned with the essential features of transmedia storytelling by investing in content expansion using different media platforms technological advancements, the coverage presented limited mechanisms of audience participation. Several technological innovations, such as virtual holographic projections of athletes, augmented reality, and $8 \mathrm{~K}$ ultra-high-definition transmissions, provided the audience with a kind of immersive experience, in which the public could feel absorbed in the coverage. The Brazilian treatment of the Rio Olympics represents an advance in the transmedia coverage of planned events, in comparison with Globo Network previous approach of news coverage during similar major events. Therefore, 
transmedia planning and the integration of multiple media platforms to disseminate content via mobile applications, Internet live-streaming and on social media networks, and an immersive experience based on technological innovations were the transmedia highlights of the Globo Network coverage. However, improvements in audience engagement, especially in terms of citizen participation, still need to be achieved. 


\section{References}

Barkho, G. (2016, August 11). How social media changed the Olympics, and what it means for \#Rio2016. Later. Retrieved from https:// bit.ly/2ArUJun

Bolin, G. (2007). Media technologies, transmedia storytelling and commodification. In T. Storsul \& D. Stuedahl (Eds.), Ambivalence towards convergence: Digitalization and media change (pp. 237-248). Gothenburg, Sweden: Nordicom.

Bromwich, J. E. (2016, August 9). “The girl from Ipanema” goes walking again, with Gisele Bundchen's help. The New York Times. Retrieved from https://nyti.ms/2BE9p9k

Bruns, A. (2008). Blogs, Wikipedia, Second Life, and beyond: From production to produsage. New York, NY: Peter Lang.

Dayan, D., \& Katz, E. (1992). Media events: The live broadcasting of history. Cambridge, MA: Harvard University Press.

Fast, K., \& Örnebring, H. (2015). Transmedia world-building: The Shadow (1931-present) and Transformers (1984-present). International Journal of Cultural Studies, 20(6), 636-652. doi: https://doi. org/10.1177/1367877915605887

Feltrin, R. (2016, August 21). Exclusivo: Globo investiu US\$250 milhões na Rio 2016 [Exclusive: Globo invested US\$250 million on Rio 2016]. UOL. Retrieved from https://bit.ly/2Q40eUM

Fox, A. (Ed.). (2016). Global perspectives on media events in contemporary society. Hershey, PA: IGI Global.

Freeman, M. (2016a). Industrial approaches to media: A methodological gateway to industry studies. London, England: Palgrave Macmillan.

Freeman, M. (2016b). Historicising transmedia storytelling: Early twentiethcentury transmedia story worlds. New York, NY: Routledge.

G1. (2016, August 28). Rio 2016 é evento mais “instagramado” da história [Rio 2016 is the most "instagramed" event in history]. G1. Retrieved from https://glo.bo/2Ah87B4 
Gambarato, R. R. (2012). Signs, systems and complexity of transmedia storytelling. Communication Studies, 12, 69-83. Available in https://bit. ly/2EMHHKM

Gambarato, R. R. (2013). Transmedia project design: Theoretical and analytical considerations. Baltic Screen Media Review, 1, 80-100. Available in https://bit.ly/2EW5WHk

Gambarato, R. R., Alzamora, G., \& Tárcia, L. (2016). Russian news coverage of the 2014 Sochi Winter Olympic Games: A transmedial analysis. International Journal of Communication, 10, 1446-1469. Available in https://bit.ly/2Sljhfd

Gambarato, R. R., Alzamora, G., Tárcia, L., \& Jurno, A. (2017). 2014 FIFA World Cup on the Brazilian Globo Network: A transmedia dynamics? Global Media and Communication, 13(3), 283-301. doi: https://doi. org/10.1177/1742766517734256

Gambarato, R. R., \& Tárcia, L. (2017). Transmedia strategies in journalism: An analytical model for the coverage of planned events. Journalism Studies, 18(11), 1381-1399. doi: https://doi.org/10.1080/146 1670X.2015.1127769

Gambarato, R. R., \& Alzamora, G. (Eds.). (2018). Exploring Transmedia Journalism in the Digital Age. Hershey, PA: IGI Global.

Getz, D. (2012). Event studies: Theory, research and policy for planned events. New York, NY: Routledge.

Gottfried, J., \& Shearer E. (2016). News use across social media platforms 2016. Washington, DC: Pew Research Center. Retrieved from https:// pewrsr.ch/27TOfhz

Hepp, A., \& Couldry, N. (2010). Introduction: Media events in globalized media cultures. In N. Couldry, A. Hepp, \& F. Krotz (Eds.), Media events in a global age (pp. 1-20). London, England: Routledge.

Jenkins, H. (2006). Convergence Culture: Where Old and New Media Collide. New York, NY: New York University Press.

Lewis, S. (2012). The tension between professional control and open participation. Information, Communication \& Society, 15(6), 836-866. doi: https://doi.org/10.1080/1369118X.2012.674150

Lobo, A. P. (2016, August 8). Globo usa DWDM nacional para transmitir em 8K na Rio 2016 [Globo uses national DWDM to broadcast in 8K in 
Rio 2016]. Convergência Digital. Retrieved from https://bit.ly/2RlcCoe Long, M. (2016, August 4). Globo gathering: How Brazil's biggest broadcaster is tackling Rio 2016. SportsPro. Retrieved from https://bit. ly/2CA0HL9

Mermelstein, A. (2016, August 26). Olimpíada impulsionou Globo em diversas plataformas [Olympics boosted Globo Network in various platforms]. Converge Comunicações. Retrieved from https://bit.ly/2EQwxVw Mitu, B., \& Poulakidakos, S. (Eds.). (2016). Media events: A critical contemporary approach. Basingstoke, England: Palgrave Macmillan.

Moloney, K. T. (2011). Porting transmedia storytelling to journalism (Unpublished master's thesis). University of Denver, Denver, CO.

Newman, N., Fletcher, R., Levy, D. A. L., \& Nielsen, R. K. (2016). Reuters Institute digital newes report 2016. Oxford, England: Reuters Institute for the Study of Journalism. Retrieved from https://bit.ly/1UT82DM O'Riordan, C. (2012, August 13). The story of the digital Olympics: Streams, browsers, most watched, four screens. $B B C$. Retrieved from https://bbc.in/2BFFBsP

Rede Globo. (2016a, August 3). Rio 2016: Globo e Snapchat fecham parceria para produção de conteúdo [Rio 2016: Globo and Snapchat agree on partnership for content production]. Rede Globo. Retrieved from https://glo.bo/2b8NERu

Rede Globo. (2016b, July 29). Aplicativo Globo Rio 2016: Guia de serviços e realidade aumentada; baixe [Rio 2016 Globo Application: Service guide and augmented reality; download it]. Rede Globo. Retrieved from https://glo.bo/2Q3YY3T

Rede Globo. (2016c, July 29). Globo estreia estúdio no coração dos Jogos Olímpicos no domingo, dia 31 [Globo launches studio in the heart of the Olympic Games on Sunday, 31]. Rede Globo. Retrieved from https:// glo.bo/2QR2uUx

Renó, D. (2014). Transmedia journalism and the new media ecology: Possible languages. In D. Renó, C. Campalans, S. Ruiz, \& V. Gosciola (Eds.), Periodismo transmedia: Miradas múltiples [Transmedia journalism: Multiple perspectives] (pp. 3-19). Barcelona, Spain: Editorial UOC. Smith, A., Stavros, C., \& Westberg, K. (2017). Brand fans: Lessons from the world's greatest sporting brands. Melbourne, Australia: Palgrave Macmillan. 
Soutelo, N. (2016, August 26). O que as redes sociais fizeram pelas Olimpíadas e o que também podem fazer pela sua marca [What have social media networks done for the Olympics and what they can also do for your brand]. SocialBrain. Retrieved from https://bit.ly/2EO1mdh Stycer, M. (2016, August 25). Audiência do SporTV na Rio-2016 foi maior que a soma de todos os concorrentes [SporTV's audience during the 2016 Rio Olympics was bigger than the sum of all other concurrents]. Blog do Mauricio Stycer. Retrieved from https://bit.ly/2BIACYl UOL. (2015, December 10). Globo assegura direitos de transmissão das Olimpíadas até 2032 [Globo ensures the Olympic broadcast rights until 2032]. Retrieved from https://bit.ly/2rT8Yn6 